\title{
WEST NILE VIRUS INFECTION WITH NEUROLOGICAL DISORDERS: A CASE REPORT AND A BRIEF REVIEW OF THE SITUATION IN BULGARIA
}

\author{
Magdalena Baymakova ${ }^{1}$, Iva Christova ${ }^{2}$, Elitsa Panayotova ${ }^{2}$, Iva Trifonova ${ }^{2}$, \\ Aleksandar Chobanov ${ }^{3}$, Ivaylo Daskalov ${ }^{3}$, Georgi T. Popov ${ }^{1}$ and Kamen Plochev ${ }^{1}$ \\ ${ }^{1}$ Department of Infectious Diseases, Military Medical Academy, Sofia, Bulgaria; \\ ${ }^{2}$ Department of Microbiology, National Center of Infectious and Parasitic Diseases, Sofia, Bulgaria; \\ ${ }^{3}$ Emergency Center, Military Medical Academy, Sofia, Bulgaria
}

SUMMARY - A case of a 66-year-old man with West Nile neuroinvassive disease manifested with fever, weakness, fatigue, consciousness disorders and underlying diabetes mellitus type 2 and cardiovascular diseases is presented. Laboratory data showed elevated erythrocyte sedimentation rate and fibrinogen. Serological tests revealed West Nile virus specific antibodies of class IgM and IgG in serum. West Nile virus RNA was detected in urine sample. Supportive therapy was applied.

Key words: West Nile virus; West Nile fever; Antibodies; RNA, Viral; Nervous system diseases; Case reports; Bulgaria

\section{Introduction}

West Nile virus (WNV), a single-stranded RNA virus, is a mosquito-borne flavivirus (family Flaviviri$d a e)^{1}$. The natural cycle is realized by transmission between mosquitoes of Culex spp. and several bird species $^{2}$. Horses and humans are incidental dead-end hosts $^{3}$. Generally, human infections are asymptomatic, acute febrile syndrome is presented in $10 \%-20 \%$ of cases, and less than $1 \%$ of them developed neuroinvasive disease ${ }^{3}$. The first large outbreak in Europe was in Romania in $1996^{4}$. Since then, sporadic cases were reported until another outbreak occurred in Greece in $2010^{5}$. Reports followed on human outbreaks or sporadic cases in countries from south-east Europe (Bulgaria, Croatia, Greece, Romania, Serbia, Turkey) $)^{6-13}$.

A case report of laboratory confirmed human case of WNV infection with neurological symptoms and favorable outcome is presented.

Correspondence to: Magdalena Baymakova, $M D$, $P h D$, Department of Infectious Diseases, Military Medical Academy, St. Georgi Sofiyski 3, BG-1606 Sofia, Bulgaria

E-mail: dr.baymakova@gmail.com

Received February 8, 2017, accepted October 10, 2017

\section{Case Report}

A 66-year-old man presented to the Emergency Center, Military Medical Academy, Sofia, Bulgaria, on September 7, 2016, because of low-grade fever, palpitation, fatigue, extremity weakness, dizziness, headache, and brief loss of consciousness three days before hospital admission. The man had concomitant diabetes mellitus type 2, hypertension, paroxysmal atrial fibrillation, mitral valve regurgitation and tricuspid valve regurgitation. The patient was a retiree and lived in Sofia. He did outdoor activities such as fishing and hiking and mentioned mosquito bites during the summer of 2016. Upon admission, he was afebrile, conscious, with blood pressure 150/80 $\mathrm{mm} \mathrm{Hg}$, heart rate 90/ min; the rest of physical examination did not show any abnormalities. Neurological examination did not estimate neck stiffness or symptoms of Kernig and Brudzinski at the time of hospitalization. The main laboratory findings were as follows: white blood cell count $7.3 \times 10^{9} / \mathrm{L}$ (reference range: $3.5-10.5 \times 10^{9} / \mathrm{L}$ ), platelets $144 \times 10^{9} / \mathrm{L}\left(150-400 \times 10^{9} / \mathrm{L}\right)$, hemoglobin $146 \mathrm{~g} / \mathrm{L}$ (130-180g/L), erythrocyte sedimentation rate $50 \mathrm{~mm} / \mathrm{h}$ ( $\leq 20 \mathrm{~mm} / \mathrm{h}$ ), blood glucose $9.4 \mathrm{mmol} / \mathrm{L}$ (3.5-5.6 
$\mathrm{mmol} / \mathrm{L})$, creatinine $112 \mu \mathrm{mol} / \mathrm{L}(45-130 \mu \mathrm{mol} / \mathrm{L})$, urea $4.7 \mathrm{mmol} / \mathrm{L}(2.8-8.3 \mathrm{mmol} / \mathrm{L})$, aspartate aminotransferase 40 IU/L (5-40 IU/L), alanine aminotransferase 27 IU/L (5-40IU/L), creatine phosphokinase $193 \mathrm{IU} / \mathrm{L}(\leq 180 \mathrm{IU} / \mathrm{L})$, C-reactive protein $3.6 \mathrm{mg} / \mathrm{L}$ (0.0-5.0 $\mathrm{mg} / \mathrm{L})$, potassium $4.2 \mathrm{mmol} / \mathrm{L}$ (3.5-5.2 $\mathrm{mmol} / \mathrm{L})$, sodium $137 \mathrm{mmol} / \mathrm{L}$ (136-145 mmol/L), and fibrinogen $5.21 \mathrm{~g} / \mathrm{L}(2.0-4.5 \mathrm{~g} / \mathrm{L})$. Imaging investigations were done at the beginning of illness. Electrocardiogram, $\mathrm{x}$-ray and abdominal ultrasound did not show any abnormalities. Transthoracic echocardiogram revealed the underlying cardiac pathology. Empirical antimicrobial drug therapy was started (intravenous cefoperazone/sulbactam $1 \mathrm{~g}$ twice daily and amikacin $500 \mathrm{mg}$ twice daily). The patient received supportive treatment as well. In a short period of hospitalization, consciousness disorders developed and WNV infection was suspected. The man was transferred to Department of Infectious Diseases. He became aggressive and excitable with a tendency of drowsiness. Neurological examination found right facial palsy and areflexia of lower extremities. No lumbar puncture was performed as the patient refused the invasive procedure. Computed tomography of the head was normal. Serum samples were obtained for serological tests for WNV, TBEV, influenza A virus, influenza B virus and Borrelia burgdorferi. All results were negative except for the positive result for specific IgM antibodies against WNV in serum sample. On day 7 of the illness, second blood and urine samples were obtained and transferred to the National Reference Laboratory of Vector-Borne Infections, Department of Microbiology, National Center of Infectious and Parasitic Diseases, Sofia, Bulgaria. Specific WNV-IgM antibodies were detected in serum (Anti-WNV ELISA IgM, Euroimmun, Lübeck, Germany), but specific WNV-IgG antibodies were not found (Anti-WNV ELISA IgG, Euroimmun, Lübeck, Germany). Blood and urine samples were tested for WNV RNA using a commercial kit (Sacace Biotechnologies, Como, Italy). The results were negative. One week later, blood and urine samples were obtained for confirmation. The level of IgM antibodies was elevated and specific IgG antibodies against WNV were detected. WNV RNA was detected in urine sample by real-time polymerase chain reaction (PCR). Blood cultures showed no bacterial growth. Neurological manifestations were re- versible and in a few days the patient regained normal consciousness. After complex therapy, the patient was discharged. On three-month follow-up, the patient was free from any neurological complications.

\section{Discussion}

Bulgaria is situated in the south-east part of $\mathrm{Eu}^{-}$ rope, with Mediterranean climate, a field for migratory and overwintering birds. During the last decades, the neighboring countries reported human WNV outbreaks and sporadic cases in new areas ${ }^{10-17}$.

In the 2011-2016 period, the Bulgarian Reference Laboratory of Vector-Borne Infections (Sofia, Bulgaria) reported only nine human cases, of which six cases fulfilled the EU criteria for probable WNV cases and three cases were laboratory confirmed ${ }^{6-8,18}$. During these six years, only three confirmed human cases at the time of increasing emergence of WNV in Europe were recorded. It is logically to expect more human cases in Bulgaria because of the favorable geographic location, suitable climate factors, vectors, and an increasing incidence of cases along the Danube River and in northern Greece.

The seroprevalence of WNV among healthy people in Bulgaria in 11 provinces of the country showed the highest WNV seropositivity in the Sofia district ${ }^{19}$. Hadjichristodoulou et al. report 2.1\% WNV seropositivity in Greece $^{20}$. Kalaycioglu et al. and Gazi et al. identified seroprevalence of WNV in Turkey of 3.8\% and 4.3\%, respectively ${ }^{21,22}$. Obviously, the levels of WNV seropositivity are similar across south-east Europe.

The surveillance systems, veterinary control, medical attention to this infection and collaboration among different institutions in Bulgaria are unsatisfactory. Medical doctors should actively search for WNV infection and epidemiological data on mosquito bites in case of acute febrile syndrome with/without neurological signs in summer/autumn season (July-October).

The clinical case of WNV infection presented was an elderly man with concomitant diseases. Male gender is reported as predominant in Serbian and Romanian reports of WNV cases $^{11,12}$. Mean age of more than 65 years and diabetes are significantly associated with encephalitis, as reported by Popovic et al. ${ }^{12}$. Hypertension is one of the main underlying conditions estimated in European outbreaks ${ }^{9,11,12}$. Notably, these concomitant diseases increased the chance for WNV 
manifestation with neuroinvasive disease in patients presenting neurological signs, while involvement of the nervous system in the development of WNV infection has been recognized as a tendency in the last decade in Europe, mainly associated with establishment of WNV lineage 2 in the continent ${ }^{14,23}$.

In conclusion, a case report of a 66-year-old man with underlying diabetes mellitus type 2 and cardiovascular diseases, who developed consciousness disturbances and neurological signs as a result of neuroinvasive infection with $\mathrm{WNV}$ is presented. The etiological agent was laboratory confirmed based on the EU recommendation $^{18}$. Specific antibodies of IgM and IgG classes against $\mathrm{WNV}$ were found in serum samples. WNV RNA was detected by real-time PCR in urine sample $^{24}$. Complex clinical symptoms, physical findings and laboratory investigations confirmed the clinical case of WNV infection in an elderly man with neurological signs, who recovered without consequences.

\section{References}

1. Khabbaz R, Bell BP, Schuchat A, Ostroff SM, Moseley R, Levitt $\mathrm{A}$, et al. Emerging and reemerging infectious disease threats. In: Bennett JE, Dolin R, Blaser MJ, editors. Mandell, Douglas, and Bennett's Principles and Practice of Infectious Diseases. $8^{\text {th }}$ edn. Philadelphia, USA: Elsevier Saunders; 2015. p. 158-77.

2. Rossi SL, Ross TM, Evans JD. West Nile virus. Clin Lab Med. 2010;30:47-65. http://dx.doi.org/10.1016/j.cll.2009.10.006

3. Petersen LR, Brault AC, Nasci RS. West Nile virus: review of the literature. JAMA. 2013;310:308-15. http://dx.doi.org/ 10.1001/jama.2013.8042

4. Tsai TF, Popovici F, Cernescu C, Campbell GL, Nedelcu NI. West Nile encephalitis epidemic in southeastern Romania. Lancet. 1998;352:767-71. http://dx.doi.org/10.1016/S01406736(98)03538-7

5. Papa A, Danis K, Baka A, Bakas A, Dougas G, Lytras T, et al. Ongoing outbreak of West Nile virus infections in humans in Greece, July-August 2010. Euro Surveill. 2010;15:19644. http://www.eurosurveillance.org/ViewArticle.aspx?ArticleId= 19644

6. Christova I, Igova D. Clinical case: viral meningitis with virusneutralizing antibodies against West Nile fever virus. Med Digest. 2012;9:22-3. (in Bulgarian)

7. Baymakova M, Panayotova E, Christova I, Dakova S, Mihaylova-Garnizova R, Ramshev K, et al. West Nile virus infection in a Bulgarian man: a case report. Probl Infect Parasit Dis. 2014; 42:20-1. http://www.ncipd.org/index.php?option=com_docman\&view=download\&alias=24-broi-42-2-2014-g-na-problems-of-infectious-and-parasitic-diseases\&category_slug=arhiv-2014\&Itemid=1121\&lang=bg
8. Baymakova M, Trifonova I, Panayotova E, Dakova S, Pacenti M, Barzon L, et al. Fatal case of West Nile neuroinvasive disease in Bulgaria. Emerg Infect Dis. 2016;22:2203-4. http:// dx.doi.org/10.3201/eid2212.151968

9. Pem-Novosel I, Vilibic-Cavlek T, Gjenero-Margan I, Pandak N, Peric L, Barbic L, et al. First outbreak of West Nile virus neuroinvasive disease in humans, Croatia, 2012. Vector Borne Zoonotic Dis. 2014;14:82-4. http://dx.doi.org/10.1089/vbz. 2012.1295

10. Pervanidou D, Detsis M, Danis K, Mellou K, Papanikolaou E, Terzaki I, et al. West Nile virus outbreak in humans, Greece, 2012: third consecutive year of local transmission. Euro Surveill. 2014;19:20758. http://dx.doi.org/10.2807/1560-7917. ES2014.19.13.20758

11. Dinu S, Cotar AI, Panculescu-Gatej IR, Falcuta E, Prioteasa FL, Sirbu A, et al. West Nile virus circulation in south-eastern Romania, 2011 to 2013. Euro Surveill. 2015;20:21130. http:// dx.doi.org/10.2807/1560-7917.ES2015.20.20.21130

12. Popovic N, Milosevic B, Urosevic A, Poluga J, Lavadinovic L, Nedeljkovic J, et al. Outbreak of West Nile virus infection among humans in Serbia, August to October 2012. Euro Surveill. 2013;18:20613. http://dx.doi.org/10.2807/1560-7917. ES2013.18.43.20613

13. Ozkul A, Ergunay K, Koysuren A, Alkan F, Arsava EM, Tezcan $\mathrm{S}$, et al. Concurrent occurrence of human and equine West Nile virus infections in Central Anatolia, Turkey: the first evidence for circulation of lineage 1 viruses. Int J Infect Dis. 2013;17:e546-51. http://dx.doi.org/10.1016/j.ijid.2013.02.005

14. Papa A, Bakonyi T, Xanthopoulou K, Vazquez A, Tenorio A, Nowotny N. Genetic characterization of West Nile virus lineage 2, Greece, 2010. Emerg Infect Dis. 2011;17:920-2. http: //dx.doi.org/10.3201/eid1705.101759

15. Sambri V, Capobianchi M, Charrel R, Fyodorova M, Gaibani $\mathrm{P}$, Gould E, et al. West Nile virus in Europe: emergence, epidemiology, diagnosis, treatment, and prevention. Clin Microbiol Infect. 2013;19:699-704. http://dx.doi.org/10.1111/14690691.12211

16. Papa A, Tsimitri T, Papadopoulou E, Testa T, Adamidis A, Gavana $\mathrm{E}$, et al. Molecular detection and isolation of West Nile virus from a human case in northern Greece, 2013. New Microbes New Infect. 2013;1:30-1. http://dx.doi.org/10.1002/ 2052-2975.17

17. Di Sabatino D, Bruno R, Sauro F, Danzetta ML, Cito F, Iannetti S, et al. Epidemiology of West Nile disease in Europe and in the Mediterranean basin from 2009 to 2013. BioMed Res Int. 2014;2014:907852. http://dx.doi.org/10.1155/2014/ 907852

18. European Commission. Commission Decision of 28 April 2008 amending Decision 2002/253/EC laying down case definitions for reporting communicable diseases to the Community network under Decision No 2119/98/EC of the European Parliament and of the Council. 18 June 2008: L 159. 
19. Panayotova E. Prevalence of some Bunyaviruses and Flaviviruses in Bulgaria. Doctoral dissertation. National Center of Infectious and Parasitic Diseases, Sofia, Bulgaria, December 20, 2016. (in Bulgarian)

20. Hadjichristodoulou C, Pournaras S, Mavrouli M, Marka A, Tserkezou P, Baka A, et al. West Nile virus seroprevalence in the Greek population in 2013: a nationwide cross-sectional survey. PLoS One. 2015;10:e0143803. http://dx.doi.org/ 10.1371/journal.pone.0143803

21. Kalaycioglu H, Korukluoglu G, Ozkul A, Oncul O, Tosun S, Karabay O, et al. Emergence of West Nile virus infections in humans in Turkey, 2010 to 2011. Euro Surveill. 2012;17:20182. http://www.eurosurveillance.org/ViewArticle.aspx?ArticleId= 20182
22. Gazi H, Ozkutuk N, Ecemis O, Atasoylu G, Koroglu G, Kurutepe $\mathrm{S}$, et al. Seroprevalence of West Nile virus, CrimeanCongo hemorrhagic fever virus, Francisella tularensis and Borrelia burgdorferi in rural population of Manisa, western Turkey. J Vector Borne Dis. 2016;53:112-7.

23. Barzon L, Papa A, Lavezzo E, Franchin E, Pacenti M, Sinigaglia $\mathrm{A}$, et al. Phylogenetic characterization of Central/Southern European lineage 2 West Nile virus: analysis of human outbreaks in Italy and Greece, 2013-2014. Clin Microbiol Infect. 2015;21: 1122.e1-e10. http://dx.doi.org/10.1016/j.cmi.2015.07.018

24. Barzon L, Pacenti M, Franchin E, Squarzon L, Sinigaglia A, Ulbert $\mathrm{S}$, et al. Isolation of West Nile virus from urine samples of patients with acute infection. J Clin Microbiol. 2014;52: 3411-3. http://dx.doi.org/10.1128/JCM.01328-14

Sažetak

\section{INFEKCIJA VIRUSOM ZAPADNOG NILA S NEUROLOŠKIM POREMEĆAJIMA: PRIKAZ SLUČAJA I KRATAK PREGLED STANJA U BUGARSKOJ}

\section{Baymakova, I. Christova, E. Panayotova, I. Trifonova, A. Chobanov, I. Daskalov, G. T. Popov i K. Plochev}

Prikazuje se slučaj 66-godišnjeg bolesnika s neuroinvazivnom bolešću Zapadnog Nila koja se manifestirala groznicom, umorom, poremećajem svijesti uz osnovnu bolest dijabetesa tipa $2 \mathrm{i}$ kardiovaskularnom bolešću. Laboratorijski podaci pokazali su povišenu sedimentaciju i fibrinogen. Serološki testovi utvrdili su protutijela specifična za virus Zapadnog Nila klase IgM i IgG u serumu. Virusna RNA otkrivena je u uzorku mokraće. Primijenjena je suportivna terapija.

Ključne riječi: Virus Zapadnog Nila; Groznica Zapadnog Nila; Antitijela; RNA, virusna; Neurološke bolesti; Prikazi slučaja; Bugarska 